\title{
"The effect of profitability, size and Shariah supervisory board of an Indonesian Islamic bank on the Islamic social reporting disclosure"
}

\begin{tabular}{|c|c|}
\hline AUTHORS & $\begin{array}{l}\text { Fachrurrozie (D) } \\
\text { Ahmad Nurkhin (D) } \\
\text { R } \\
\text { Agus Wahyudin (D) } \\
\text { Al Mamnukhin Kholid (D) } \\
\text { Ika Agustina (D) }\end{array}$ \\
\hline ARTICLE INFO & $\begin{array}{l}\text { Fachrurrozie, Ahmad Nurkhin, Agus Wahyudin, Al Mamnukhin Kholid and lka } \\
\text { Agustina (2021). The effect of profitability, size and Shariah supervisory board of } \\
\text { an Indonesian Islamic bank on the Islamic social reporting disclosure. Banks and } \\
\text { Bank Systems, 16(3), 84-92. doi:10.21511/bbs.16(3).2021.08 }\end{array}$ \\
\hline DOI & http://dx.doi.org/10.21511/bbs.16(3).2021.08 \\
\hline RELEASED ON & Tuesday, 14 September 2021 \\
\hline RECEIVED ON & Saturday, 07 November 2020 \\
\hline ACCEPTED ON & Monday, 06 September 2021 \\
\hline LICENSE & $\begin{array}{l}(c) \text { EY } \\
\text { This work is licensed under a Creative Commons Attribution } 4.0 \text { International } \\
\text { License }\end{array}$ \\
\hline JOURNAL & "Banks and Bank Systems" \\
\hline ISSN PRINT & $1816-7403$ \\
\hline ISSN ONLINE & $1991-7074$ \\
\hline PUBLISHER & LLC "Consulting Publishing Company "Business Perspectives" \\
\hline FOUNDER & LLC "Consulting Publishing Company "Business Perspectives" \\
\hline
\end{tabular}

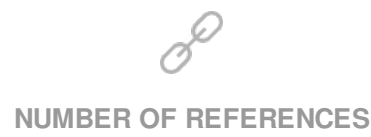

34
NUMBER OF FIGURES

1
NUMBER OF TABLES

3

(C) The author(s) 2021. This publication is an open access article. 


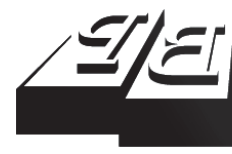

\section{BUSINESS PERSPECTIVES}

(O)

LLC "CPC "Business Perspectives"

Hryhorii Skovoroda lane, 10, Sumy, 40022, Ukraine

www.businessperspectives.org
Received on: $7^{\text {th }}$ of November, 2020 Accepted on: $6^{\text {th }}$ of September, 2021 Published on: $14^{\text {th }}$ of September, 2021

(C) Fachrurrozie, Ahmad Nurkhin, Agus Wahyudin, Al Mamnukhin Kholid, Ika Agustina, 2021

Fachrurrozie, M.Si., Lecturer, Faculty of Economics, Universitas Negeri Semarang, Indonesia.

Ahmad Nurkhin, M.Si., Lecturer, Faculty of Economics, Universitas Negeri Semarang, Indonesia. (Corresponding author)

Agus Wahyudin, Dr., Lecturer, Faculty of Economics, Universitas Negeri Semarang, Indonesia.

Al Mamnukhin Kholid, KH. Supervisor, Al Asror Islamic Boarding School, Semarang, Indonesia.

Ika Agustina, S.Pd., Researcher, Faculty of Economics, Universitas Negeri Semarang, Indonesia.
Fachrurrozie (Indonesia), Ahmad Nurkhin (Indonesia), Agus Wahyudin (Indonesia), Al Mamnukhin Kholid (Indonesia), Ika Agustina (Indonesia)

\section{THE EFFECT OF PROFITABILITY, SIZE AND SHARIAH SUPERVISORY BOARD OF AN INDONESIAN ISLAMIC BANK ON THE ISLAMIC SOCIAL REPORTING DISCLOSURE}

\begin{abstract}
This paper analyzes the effect of profitability and size of Indonesian Islamic banks on the level of Islamic Social Reporting (ISR) disclosure. This study also investigates the role played by the Sharia Supervisory Board (SSB) in the effect of profitability and size of an Islamic bank on ISR disclosure. The presence of SSB is very important in the operations of Islamic banks. SSB should be involved in important company decisions, including the ISR disclosure. The study covers all 14 Indonesian Islamic commercial banks as a population; the analysis will be conducted based on annual reports of the banks' divisions for the period 2014-2018. A documentation technique was used to collect the data. Moderated Regression Analysis (MRA) was used for data analysis. The results show that the adjusted R-squared coefficient of the equation is 0.341 . R-squared contributions of ROA, ROE, size, and SSB are $-0.093,0.010,0.983$, and -0.081 . Other results show that profitability (ROA) and size (total assets) significantly affect the level of ISR disclosure among Indonesian Islamic banks. However, the results were indifferent regarding the role of SSB. There is no significant effect of SSB on ISR disclosure. SSB was important for moderating the relationship between profitability (ROA and ROE) and bank size and ISR disclosure level. SSB's involvement in the decision making of Islamic banks will have a positive effect on the activities of Islamic banks. Islamic banks will tend to have a high level of ISR. Further researchers can develop SSB measurements for more accurate results.
\end{abstract}

Keywords

return on assets, return on equity, assets, ISR disclosure, SSB members

\section{JEL Classification $\quad$ M41, G20, G30}

\section{INTRODUCTION}

Islamic social reporting (ISR) is a concept that arose out of corporate social responsibility (CSR) and is based on the Islamic sharia principles. According to Astuti and Nurkhin (2019), CSR is born when a profit-oriented firm starts focusing on the 3Ps or triple bottom line, which includes Profit, Planet and People. ISR is based on the teachings of Qur'an, which mandates human beings to be caliphs on earth - it is their responsibility to take care of Allah's entire creation. This can be referenced back to the Qur'an surah Al-A'raf verse 71, whereby humans are commanded as caliphs to help preserve Allah's creation. Under the theoretical terms, ISR is viewed as being in accordance with the Sharia Enterprise Theory (SET), whereby humans' beings as Khalifa fil ardhi are mandated to be obedient to all the provisions of Allah, as He is the center of everything. According to Khoirudin (2013), the concepts of ISR can also be drawn from the legitimacy and stakeholder theory. 
Islamic banking in Indonesia provides the best theater required to study ISR practices even though previous studies have reported low incidences of ISR practices. For example, a study by Santoso and Dhiyaul-haq (2017) shows that the rate of ISR disclosure in Indonesian Islamic banks remains low at $46.39 \%$, while Wahyuni (2018) argues that this rate was much higher at 56.94\%, with Pratama et al. (2018) pointing towards a much higher average rate of $60.44 \%$ (Pratama et al., 2018).

There are several factors behind low ISR disclosure among Indonesian banks such as the presence of Sharia supervisory board (SSB), firm size and profitability, among others. According to Santoso and Dhiyaul-haq (2017), companies that report higher profits often change the policies to their benefit in areas such as social responsibility disclosures. This is because, according to Othman et al. (2009), a large-sized firm will often have at its disposal an increased level of resources ranging from the human, facility, and financial resources.

However, the results of previous studies show that the effect of profitability and firm size is still not consistent. The study tries to present the role of SSB to strengthen the influence of profitability and firm size on ISR disclosure. SSB will be tested as a moderating variable of the relationship between profitability and size of Islamic banks and the level of ISR disclosure. The existence of SSB is still believed to be able to play an important role in the activities of Islamic banks, including social activities and reporting. SSB is an organ that really distinguishes Islamic banks from banks in general. The tasks to be solved in this study are as follows:

1) analyze the effect of profitability on ISR disclosure of Indonesian Islamic banks;

2) analyze the effect of Indonesian Islamic bank size on ISR Disclosure;

3) analyze the effect of SSB of Indonesian Islamic banks on ISR disclosure; and

4) investigate the role of SSB as a moderator variable in the relationship between profitability and size of an Islamic bank and ISR disclosure.

\section{LITERATURE REVIEW AND HYPOTHESIS DEVELOPMENT}

The concept of Islamic Social Reporting is based on the principles of the Sharia Enterprise Theory, which is combined with a variety of Islamic values to help create both humanist and transcendental theories. A huge presumption required in developing the comprehension of the Sharia Enterprise Theory is that all the resources and trust owned by stakeholders are from Allah (Kalbarini, 2018). The stakeholder theory also plays a significant role in the ISR practice. According to Freeman and Vea (2001), all companies within the framework of stakeholder theory are responsible and loyal to parties that have both internal and external influence on them.

ISR can also be referred to as a concept that seeks not only to show the role of companies in developing the economic aspects of communities, but also the spiritual aspect. According to Haniffa (2002), the framework of Islamic Social Reporting is based on three key dimensions, such as seeking wealth to fulfill needs, benefiting the community, and seeking the pleasure of Allah. Under the Islamic view, the purpose of Social Reporting is to increase a firm's level of transparency and accountability to the community and to Allah SWT (Mais \& Lufian, 2018). This can be done through the provision of information, remaining Shariacompliant in decision making and meeting the spiritual needs of all the Muslim investors.

There are several factors that influence the Islamic banks' disclosure of ISR. This study tries to examine the effect of profitability and size of Islamic banks on the level of ISR disclosure. The role of SSB also will be tested. The SSB will be a moderating variable that strengthens the impact of profitability and size of a firm in relation to its level of ISR disclosure. The problem under study revolves around the role that a Sharia supervisory board plays in the relationship between profitability and 
size of Indonesian Islamic banks to their level of ISR disclosure. Siddi et al. (2019) argued that profitability is one of the factors that allows companies to be flexible and free to participate in social responsibility. That is, the higher level of profitability of Islamic banks will lead to an increase in ISR disclosure.

Previous research shows that there are differences in the effect of profitability on the level of ISR disclosure. Previous studies found a positive impact of the profitability of a firm on the level of ISR disclosure (Widayuni \& Harto, 2014; Anggraini \& Wulan, 2017; Rostiani \& Sukanta, 2018), while others pointed that there was no effect of profitability on the level of disclosure (Khotijah et al., 2019; Purwani et al., 2018; Umiyati \& Baiquni, 2018; Sunarsih \& Ferdiyansyah, 2017).

Adnan et al. (2016) explained that firm size is a key factor that helps assess the size of an organization. Therefore, there greater the Islamic bank is, the greater is the expectation that it will increase its level of ISR disclosure. The size of a firm helps identify the level of complexity of a bank or firm. For example, large firms will often involve a variety of activities and thereby need more supervision compared to small companies. Previous studies indicate various findings. Some studies show that there is a positive relationship between the firm size and the level of ISR disclosure, while others show that there is no correlation between the two (Pratama et al., 2018; Rama \& Meliawati, 2014; Mukhibad, 2018; Mukhibad \& Fitri, 2020; Putra et al., 2020; Khotijah et al., 2019).

One of the major differences between Islamic banks and conventional banks is that Islamic financial institutions have an SSB, whose duty as stated under the Article PBI (Peraturan Bank Indonesia) No. 11/3/PBI/2009 of the Islamic Commercial Banks is to offer advisory services and ensure that all the banking activities are carried out in accordance with all the Sharia principles. Key studies report that the presence of SSB is critical to the engagement in ISR disclosure activities. Rustam (2013) shows that SSB are Sharia experts that are appointed at the Sharia General Meeting of Shareholders having been recommended by the Indonesian Ulema Council (MUI) to help ensure that banks uphold Sharia principles and help oversee a firm's activities. Farook et al. (2011) reveal that SSB does play a role in increasing the level of ISR disclosure as they ensure the firm follows any Sharia principles. Mukhibad (2018) postulates a positive relationship between SSB and ISR disclosure. These results resonate with similar results obtained by Ningrum et al. (2013) and Eksandy and Hakim (2018). Using SSB to measure corporate governance, Mubarok (2019) has shown that SSB has a significant effect on ISR disclosure.

The purposes of this study are:

1) to analyze the effect of profitability of Indonesian Islamic banks on the level of ISR disclosure;

2) to analyze the effect of size of Indonesian Islamic banks on the level of ISR disclosure;

3) to analyze the effect of SSB of Indonesian Islamic banks on the level of ISR disclosure;

4) to investigate the role of SSB as a moderating variable in the relationship between profitability, size, and the level of ISR disclosure of Indonesian Islamic banks.

Based on the literature review, the following hypotheses are formulated:

H1a: ROA has a positive and significant effect on ISR disclosure.

H1b: ROE has a positive and significant effect on ISR disclosure.

H2: Firm size has a positive and significant effect on ISR disclosure.

H3a: SSB has a positive and significant effect on ISR disclosure.

H3b: SSB significantly moderates the relationship between profitability and ISR disclosure.

H3c: SSB significantly moderates the relationship between firm size and ISR disclosure.

The framework of this study is shown in Figure 1. 


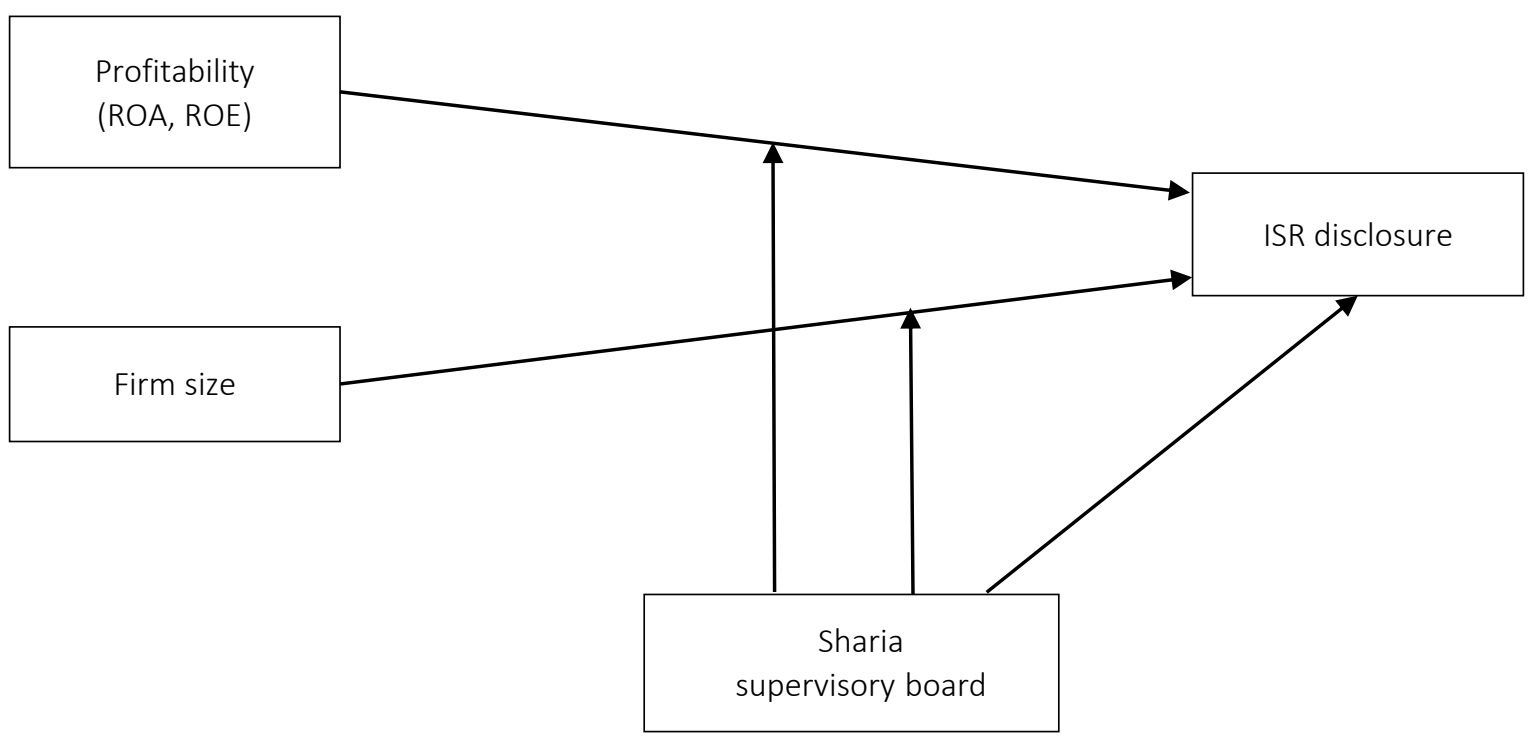

Figure 1. Conceptual framework

\section{METHODS}

All Indonesian Islamic commercial banks are involved in the study. All the banks included in the study have an annual report analysis unit. By the end of September 2019, Indonesia had 14 Islamic commercial banks. The time observation is a five-year period from 2014 to 2018. This period will be sufficient to provide accurate and relevant results that will help you better understand the ISR disclosure terms.

The study used a purposive sampling technique with the following criteria:

a) the Islamic bank was registered in Indonesia between 2014 and 2018;

b) the Islamic bank submits annual reports for the selected period consecutively.
ISR disclosure is a dependent variable. The size and profitability of a firm are independent variables. The Sharia supervisory board will be a moderating variable.

The study relied on secondary data collected from annual reports of Indonesian Islamic commercial banks from 2014 to 2018. Furthermore, data was collected using a documentation technique. The study then used a content analysis to assess a firm's level of ISR disclosure in relation to the firm's annual report analysis unit. The content analysis obtained the following results: the ISR index by theme, the lowest ISR index, the highest ISR index, and the ISR index by the year. Later, the study used moderated regression analysis as the main method for analyzing the data.

Table 1. Operational definitions of research variables

\begin{tabular}{c|c|c}
\hline No. & Research variable & Indicators \\
\hline 1 & ISR disclosure/ISRD & $\begin{array}{c}\text { Investment and financial themes } \\
\text { Product and service themes } \\
\text { Labor theme } \\
\text { Social theme } \\
\text { Environmental theme }\end{array}$ \\
\hline 2 & The existence of SSB & Organizational governance theme \\
\hdashline 3 & Profitability & The number of SSB
\end{tabular}




\section{RESULTS AND DISCUSSION}

The first results, which are fit test models, are recorded in Table 2. The AARS, ARS and APC criteria record a $\mathrm{P}$ value as less than 0.001 , which means that the model is ready for the next step.

Table 2. Model test results

\begin{tabular}{|c|c|c|c|}
\hline No. & Indicator & Result & Decision \\
\hline 1 & $\begin{array}{l}\text { Average path coefficient } \\
\text { (APC) }\end{array}$ & $\begin{array}{c}A P C=0.352 \\
P=0.002\end{array}$ & Acceptable \\
\hline 2 & $\begin{array}{l}\text { Average R-squared } \\
\text { (ARS) }\end{array}$ & $\begin{array}{c}A R S=0.435 \\
P<0.001\end{array}$ & Acceptable \\
\hline 3 & $\begin{array}{l}\text { Average adjusted } \\
\text { R-squared (AARS) }\end{array}$ & $\begin{array}{c}\text { AARS }=0.341 \\
P<0.001\end{array}$ & Acceptable \\
\hline
\end{tabular}

The next step involved testing the hypothesis, which shows that ROA is different from ROE and is a profitability proxy that affects ISRD. The results have also showed that they influenced a firm's ISR disclosure. SSB is also considered as a moderating variable that has an effect on the size and profitability of a firm and its ISR disclosure.

Table 3. Hypothesis testing

\begin{tabular}{|c|c|c|c|}
\hline No. & Hypothesis & Result & Decision \\
\hline 1 & $\begin{array}{l}\text { ROA has a positive and } \\
\text { significant influence on } \\
\text { ISRD }\end{array}$ & $\begin{array}{c}\text { P value } 0.016 \\
\text { Coefficient } 0.279\end{array}$ & Accepted \\
\hline 2 & $\begin{array}{l}\text { ROE has a positive and } \\
\text { significant influence on } \\
\text { ISRD }\end{array}$ & $\begin{array}{l}\text { P value } 0.446 \\
\text { Coefficient } \\
-0.019\end{array}$ & Rejected \\
\hline 3 & $\begin{array}{l}\text { Firm size has a positive } \\
\text { and significant influence } \\
\text { on ISRD }\end{array}$ & $\begin{array}{c}P \text { value }<0.001 \\
\text { Coefficient } 1.151\end{array}$ & Accepted \\
\hline 4 & $\begin{array}{l}\text { SSB has a positive and } \\
\text { significant influence on } \\
\text { ISRD }\end{array}$ & $\begin{array}{c}\text { P value } 0.093 \\
\text { Coefficient } \\
-0.177\end{array}$ & Rejected \\
\hline 5 & $\begin{array}{l}\text { SSB moderates the } \\
\text { relationship between ROA } \\
\text { and ISRD }\end{array}$ & $\begin{array}{c}\text { P value } 0.020 \\
\text { Coefficient } \\
-0.270\end{array}$ & Accepted \\
\hline 6 & $\begin{array}{l}\text { SSB moderates the } \\
\text { relationship between ROE } \\
\text { and ISRD }\end{array}$ & $\begin{array}{c}\text { P-value } 0,004 \\
\text { Coefficient } \\
-0.341\end{array}$ & Accepted \\
\hline 7 & $\begin{array}{l}\text { SSB moderates the } \\
\text { relationship between size } \\
\text { and ISRD }\end{array}$ & $\begin{array}{l}P \text { value } 0.041 \\
\text { Coefficient } \\
-0.230\end{array}$ & Accepted \\
\hline
\end{tabular}

\subsection{The effect of profitability on ISR disclosure}

Based on the above results, ROA had a significant positive effect on ISR compared to ROE. This shows that having a greater ROA will help in increasing the scope of ISR disclosures by
Indonesian Islamic banks. With a higher level of profitability, banks can provide broad information to their stakeholders, which is a big convenience for Islamic banks. This information will be critical in spreading awareness of the good social value of Islamic banks.

The results of this study are similar to those of the study by Rostiani and Sukanta (2018). However, other studies have come out strongly stating that a higher profitability level does not guarantee an increased level of ISR disclosure of Islamic banks (Anggraini \& Wulan, 2017). Other studies, such as by Hajawiyah et al. (2019), found that an increased level of profitability will often decrease a firm's level of ISR disclosure.

The level of Islamic bank profitability (ROA) can determine the level of ISR disclosure. Islamic banks that have a higher level of profitability will be safer in carrying out their social activities. Islamic banks can allocate their profits for the economic empowerment of the surrounding community, compensation for the poor and nature conservation. The greater profit will increase the confidence of Islamic banks to be able to carry out these social activities. Fluctuations in the rate of return obtained by Islamic banks will make banks think again about disclosing their social activities. The limited activity makes Islamic banks hesitate to disclose it in their annual reports. Thus, profitability is still of interest for further study as its role is still uncertain. Some researchers have found a positive effect of profitability on the level of ISR disclosure, while others have found the opposite.

\subsection{The effect of firm size on ISR disclosure}

Firm size is a critical factor that helps in determining the level of ISR disclosure. Huge firms such as Islamic banks that have a higher asset base will often disclose some of the information they own, and this includes ISR disclosures. This is done for them to strengthen their position and gain legitimacy among its stakeholders. Most studies in this area show that firm size has a positive influence on the ISR disclosure of a bank (Hajawiyah et al., 2019; Mukhibad, 2018; Mukhibad \& Fitri, 2020; Nugraheni \& Wijayanti, 2017; Pratama et al., 2018; Putra et al., 2020). However, like the other factors 
cited above, several studies fail to show a relationship between firm size and their level of ISR disclosure (Kasih \& Rini, 2018; Prasetyoningrum, 2018; Widayuni \& Harto, 2014).

The large size of Islamic banks would encourage a more diverse social activity. Office coverage will also increase the access of Islamic banks in carrying out social activities. Islamic banks will be closer to people who need assistance and empowerment. In addition, Islamic banks will be more flexible in utilizing their resources for charitable activities and nature conservation. Thus, the size of Islamic banks greatly affects the social activities carried out by them. ISR shows the extent to which Islamic banks make a positive contribution to social and economic empowerment of the community.

\subsection{The role of Shariah supervisory board in the effect of profitability and firm size on ISR disclosure}

The presence of SSB in Islamic banks is what sets them apart from conventional banks and is therefore expected to play a great role in determining the role and activities carried out by Islamic banks, including ISR disclosure (Farook et al., 2011). However, the results show that SSB does not have a significant or positive effect on the level of ISR disclosure. However, Eksandy and Hakim (2018) record a positive correlation between SSB and ISR disclosure (Mubarok, 2019; Mukhibad, 2018).

The implementation of social responsibility by Islamic banks is in the context of implementing the principle of accountability (Voronova \& Umarov, 2021). Because the principle of accountability is the closest principle to Islam regarding corporate social responsibility. The existence of SSB can keep an Islamic bank to remain responsible towards society and environment.

The existence of SSB has not been able to influence the level of ISR disclosure. The SSB is still considered as a complementary organ specifically aimed at monitoring the conformity of bank activities with Sharia rules. SSB has not had a direct impact on the level of ISR disclosure. SSB should be able to increase its activities and involvement in social activities and economic empowerment carried out by Islamic banks. It is hoped that Islamic banks can increase their social activities to further increase their social contribution to the surrounding community. The public will give a positive response to Islamic banks and can encourage people to use the services of Islamic banks.

This study also examines the other roles of SSB, namely as a moderator of the relationship between profitability and size of an Indonesian Islamic bank and ISR disclosure. The result indicates that SSB can play a significant role in moderating the relationship between profitability and firm size and ISR disclosure. However, the found correlation coefficient is negative. This means that the higher the number of SSB members, the less the impact of profitability and size of Indonesian Islamic banks on ISR disclosure.

The results show that SSB can significantly affect the relationship between firm size and ISR. Large Islamic banks with active involvement of SSB will increase their social activity. Thus, the ISR of Islamic banks will be even greater. SSB can do important things so that Islamic banks carry out social activities for the surrounding environment. As previously found (Alam et al., 2021), Islamic banks and other Islamic financial institutions have not been able to touch the grassroots. Islamic banks can channel their funds more to Baitul Maal wa Tamwil (BMT) or Islamic Microfinance Institution (IMFI) whose existence is very close to the community. Islamic banks can also cooperate with zakat management institutions to distribute social funds. SSB monitors social activities of Islamic banks and can recommend trustworthy zakat management institutions.

The implication of this study is the importance of enhancing the role of SSB in the ISR disclosure of Islamic banks in Indonesia. SSB can increase the activity of supervising Islamic banks in the implementation of adequate social activity. Thus, Islamic banks can better disclose ISR. The existence of SSB is highly recognized by Islamic banks in Indonesia. As such, SSB plays an important role in helping Islamic banks innovate in the social and economic empowerment activities surrounding communities. Policy makers could issue regulations to provide more access to SSB in monitoring social activities carried out by Islamic banks. 


\section{CONCLUSION}

This study tries to examine the effect of profitability and size of Indonesian Islamic banks on ISR disclosure. The paper also tests the role of SSB in the effect of profitability and size on ISR disclosure. The results indicated that ISR disclosure was determined by profitability (return on assets) and firm size significantly. However, the study has remained indifferent regarding the effect of the Sharia Supervisory Board on the level of ISR disclosure. The main finding of this study is that SSB can play a significant role in moderating the relationship between profitability and firm size and ISR disclosure. It can be concluded that SSB plays an important role in increasing ISR disclosure. Thus, improving ISR disclosure among Indonesian Islamic banks will be better if SSB can carry out their activities to supervise and monitor the social activity of banks. It is through this that banks can earn the trust of stakeholders, encouraging them to rely on the services offered by these banks.

\section{AUTHOR CONTRIBUTIONS}

Conceptualization: Fachrurrozie, Ahmad Nurkhin, Agus Wahyudin, Al Mamnukhin Kholid.

Data curation: Fachrurrozie, Ahmad Nurkhin, Al Mamnukhin Kholid, Ika Agustina.

Formal analysis: Fachrurrozie, Agus Wahyudin, Al Mamnukhin Kholid, Ika Agustina.

Funding acquisition: Fachrurrozie, Al Mamnukhin Kholid.

Investigation: Ahmad Nurkhin.

Methodology: Fachrurrozie, Ahmad Nurkhin, Agus Wahyudin.

Project administration: Ahmad Nurkhin, Ika Agustina.

Resources: Fachrurrozie, Ahmad Nurkhin, Al Mamnukhin Kholid.

Software: Ahmad Nurkhin, Ika Agustina.

Supervision: Fachrurrozie.

Validation: Fachrurrozie, Ahmad Nurkhin, Agus Wahyudin.

Visualization: Ika Agustina.

Writing - original draft: Fachrurrozie, Ahmad Nurkhin, Agus Wahyudin.

Writing - reviewing \& editing: Fachrurrozie, Ahmad Nurkhin, Agus Wahyudin.

\section{REFERENCES}

1. Adnan, A., Ridwan, R., \& Fildzah, F. (2016). Pengaruh Ukuran Bank, Dana Pihak Ketiga, Capital Adequacy Ratio, dan Loan to Deposit Ratio Terhadap Penyaluran Kredit Pada Perusahaan Perbankan yang Terdaftar Di Bursa Efek Indonesia Tahun 2011-2015. Jurnal Dinamika Akuntansi Dan Bisnis, 3(2), 49-64. https://doi. org/10.24815/jdab.v3i2.5386

2. Alam, A., Nizam, R. S., \& Hidayat, M. T. (2021). The role of islamic microfinance institution in empowering indonesian fishing communities. Universal Journal of Accounting and Finance, 9(2), 178-183. https://doi.org/10.13189/ UJAF.2021.090205

3. Anggraini, A., \& Wulan, M. (2017). Faktor Financial-Non Financial dan Tingkat Pengungkapan Islamic Social Reporting (ISR). Jurnal Akuntansi Dan Keuangan Islam, 3(2), 161-184. https://doi. org/10.35836/jakis.v3i2.35

4. Astuti, W., \& Nurkhin, A. (2019). The role of Islamic Governance on Islamic social reporting disclosure of Indonesia Islamic Banks. Proceeding of the Conference on Islamic Management, Accounting, and Economics (CIMAE) (pp. 26-36). Retrieved from https:// journal.uii.ac.id/CIMAE/article/ view/12751

5. Eksandy, A., \& Hakim, M. Z. (2018). Faktor-Faktor Yang Berpengaruh Terhadap Pengungkapan Islamic Social Reporting pada Perbankan Syariah Indonesia Periode 2011-
2015. Jurnal Akuntansi, 10(2), 187-198. https://doi.org/10.28932/ jam.v10i2.1084

6. Farook, S., Hassan, M. K., \& Lanis, R. (2011). Determinants of Corporate Social Responsibility Disclosure: the Case of Islamic Banks. Journal of Islamic Accounting and Business Research, 2(2), 114-141. https://doi. org/10.1108/17590811111170539

7. Freeman, R. E., \& Vea, J. M. (2001). A Stakeholder Approach to Strategic Management (Working Paper No. 01-02). Darden Graduate School of Business Administration, University of Virginia. Retrieved from http:// faculty.wwu.edu/dunnc3/rprnts. stakeholderapproach.pdf 
8. Hajawiyah, A., Siswantoro, D., \& Dewi, M. K. (2019). Determinants of Islamic Social Reporting in Indonesia and Malaysia. Proceedings of the Asia Pacific Business and Economics Conference (APBEC 2018) (pp. 72-77). https://doi.org/10.2991/ apbec-18.2019.11

9. Haniffa, R. (2002). Social Reporting Disclosure: An Islamic Perspective. Indonesian Management \& Accounting Research, 1(2), 128-146. Retrieved from https://kitlv-docs.library. leiden.edu/open/345610423.pdf

10. Kalbarini, R. Y. (2018). Implementasi Akuntabilitas dalam Shari'ah Enterprise Theory di Lembaga Bisnis Syariah (Studi Kasus: Swalayan Pamella Yogyakarta). Al-Tijary, 4(1), 1-12. https://doi.org/10.21093/ at.v4i1.1288

11. Kasih, A. M., \& Rini. (2018). Factors Influencing Islamic Social Reporting Disclosure in Some Selected Countries. International Conference on Islamic Finance, Economics and Business (pp. 276296). https://doi.org/10.18502/kss. v3i8.2514

12. Khoirudin, A. (2013). Corporate Governance dan Pengungkapan Islamic Social Reporting pada Perbankan Syariah di Indonesia. Accounting Analysis Journal, 2(2), 227-232. Retrieved from https:// journal.unnes.ac.id/sju/index.php/ aaj/article/view/2919

13. Khotijah, S., Malikah, A., \& Junaidi. (2019). Analisis Faktor-Faktor yang Mempengaruhi Islamic Social Responsibility. E-JRA, 8(5), 1-9. Retrieved from http://riset. unisma.ac.id/index.php/jra/article/viewFile/2479/2293

14. Mais, R. G., \& Lufian, N. (2018) Pengaruh Sharia Governance Structure Terhadap Pengungkapan CSR Berdasarkan Islamic Social Reporting Index. Jurnal Akuntansi Dan Manajemen, 15(1), 83-100. Retrieved from https://ejournal. stei.ac.id/index.php/JAM/article/ view/145

15. Mubarok, M. S. (2019). The determinants of Islamic Social Reporting Disclosure and Its
Impact on the Profitability of Sharia Banks. Journal of Islamic

Economics, Management, and Business, 1(1), 137-172. https://doi. org/10.21580/jiemb.2019.1.1.3742

16. Mukhibad, H. (2018). Peran Dewan Pengawas Syariah dalam Pengungkapan Islamic Social Reporting. Jurnal Akuntansi Multiparadigma (JAMAL), 9(2), 299-311. http://dx.doi. org/10.18202/jamal.2018.04.9018

17. Mukhibad, H., \& Fitri, A. (2020). Determinant of Islamic Social Reporting (ISR) Disclosure. KnE Social Sciences, 478-489. https:// doi.org/10.18502/kss.v4i6.6620

18. Ningrum, R. A., Fachrurrozie, \& Jayanto, P. Y. (2013). Pengaruh Kinerja Keuangan, Kepemilikan Institusional, dan Ukuran Dewan Pengawas Syariah terhadap Pengungkapan ISR. Accounting Analysis Journal, 2(4), 430-438. Retrieved from https://journal. unnes.ac.id/sju/index.php/aaj/ article/view/4169

19. Othman, R., Thani, A. M., \& Ghani, E. K. (2009). Determinants of Islamic Social Reporting Among Top Shariah-Approved Companies in Bursa Malaysia Rohana. Research Journal of International Studies, 12, 4-20. Retrieved from http://lela.stiemj. ac.id/wp-content/uploads/Islamicsocial-reporting-Kel6.pdf

20. Prasetyoningrum, A. K. (2018). Pengaruh Ukuran Perusahaan, Profitabilitas, Leverage, Efisiensi Biaya, dan Umur Perusahaan terhadap Islamic Social Reporting pada Perbankan Syariah di Indonesia. MALIA: Journal of Islamic Banking and Finance, 2(2), 147-162. Retrieved from https://journal.iainkudus.ac.id/ index.php/syirkah/article/viewFile/4780/3083

21. Pratama, A. N. A., Muchlis, S., \& Wahyuni, I. (2018). Determinan Pengungkapan Islamic Social Reporting pada Perbankan Syariah dengan Komisaris Independen sebagai Variabel Moderating. Al-Mashrafiyah: Jurnal Ekonomi, Keuangan Dan Perbankan Syariah, 2(1), 103-115. Retrieved from http://journal. uin-alauddin.ac.id/index.php/ almashrafiyah/article/view/4738

22. Purwani, T., Nurlaela, S., \& Wijayanti, A. (2018). Size, Profitabilitas, Likuiditas, Leverage dan Tax Avoidance Terhadap Pengungkapan Islamic Social Reporting Di Indeks Saham Syariah. Indonesian Economics Business and Management Research, 1(1), 110-117. Retrieved from https://journal.uniba.ac.id/ index.php/IJEBMR/article/ view/114

23. Putra, W. E., Afrizal., Mukhzarudfa., \& Lubis, T. A. (2020). What factors Do influence Islamic social reporting (ISR) disclosure? Evidence from Indonesia. International Journal of Recent Technology and Engineering, 8(5), 50-55. https://doi. org/10.35940/ijrte.e5622.018520

24. Rama, A., \& Meliawati, M. (2014). Analisis Determinan Pengungkapan Islamic Social Reporting: Studi Kasus Bank Umum Syariah Di Indonesia. Equilibrium: Jurnal Ekonomi Syariah, 2(1), 84-103. Retrieved from https://journal.iainkudus. ac.id/index.php/equilibrium/article/view/714

25. Rostiani, S. S., \& Sukanta, T. A. (2018). Pengaruh Dewan Pengawas Syariah, Profitabilitas dan Leverage terhadap Pengungkapan Islamic Social Reporting (ISR). Jurnal Akuntansi Bisnis Dan Ekonomi, 4(2), 1225 1248. https://doi.org/10.33197/ jabe.vol4.iss2.2018.184

26. Rustam, B. R. (2013). Manajemen Risiko Perbankan Syariah di Indonesia. Jakarta: Salemba Empat.

27. Santoso, A. L., \& Dhiyaul-haq, Z. M. (2017). Determinan Pengungkapan Islamic Social Reporting pada Bank Umum Syariah di Indonesia. Jurnal Dinamika Akuntansi Dan Bisnis, 4(2), 125-142. https://doi.org/10.24815/ JDAB.V4I2.6421

28. Siddi, P., Widiastuti, L., \& Chomsatu, Y. (2019)

Pengungkapan Islamic Social Reporting (ISR) dan FaktorFaktor yang Mempengaruhinya. Surakarta Manajemen Jornal, 1(1), 
8-21. Retrieved from http://ejournal.unsa.ac.id/index.php/smj/ article/view/326

29. Suhendro, W. A., \& Wijayanti, A. (2017). Faktor-Faktor yang Mempengaruhi Pengungkapan Islamic Social Reporting (ISR). Jurnal Ekonomi Paradigma, 19(2), 68-75. Retrieved from https:// journal.uniba.ac.id/index.php/ PRM/article/view/9/0

30. Sunarsih, U., \& Ferdiyansyah, F. (2017). Determinant of the Islamic Social Reporting Disclosure. Al-Iqtishad: Jurnal Ilmu Ekonomi Syariah, 9(1), 69-80. https://doi. org/10.15408/aiq.v9i1.3771

31. Umiyati, \& Baiquni, M. D. (2018). Ukuran Perusahaan, Profirtabilitas, dan Leverage terhadap Islamic Social Reporting pada Bank Umum Syariah di Indonesia. Jurnal Akuntansi Dan Keuangan Islam, 6(1), 85-104. Retrieved from https://media.neliti.com/media/publications/266847-ukuranperusahaan-profitabilitas-dan-levd973a938.pdf

32. Voronova, E. Y., \& Umarov, H. S. (2021). Islamic (partner) accounting and its comparison with international financial accounting standards (IFRS). Universal Journal of Accounting and Finance, 9(2), 267-274. https://doi.org/10.13189/ UJAF.2021.090217

33. Wahyuni, S. (2018). Islamic Social Reporting Disclosure and
Determinant Factors: Empirical Evidence from Islamic Banks in Indonesia. Proceedings of the 5th International Conference on Community Development (AMCA 2018) (pp. 389-392). https://dx.doi.org/10.2991/amca18.2018.107

34. Widayuni, N., \& Harto, P. (2014). Faktor-Faktor yang Mempengaruhi Pengungkapan Corporate Social responsibility pada Perbankan Syariah di Indonesia dan Malaysia. Diponegoro Journal of Accounting, 3(2), 1-11. Retrieved from https://ejournal3.undip.ac.id/ index.php/accounting/article/ view/6150/5937 